\title{
Survey of potato production and possible yield constraints in Argentina
}

\author{
D.O. CALDIZ ${ }^{1}$ and P.C. STRUIK ${ }^{2}$
}

1 Instituto de Fisiología Vegetal, Facultad de Ciencias Agrarias y Forestales, Universidad Nacional de La Plata. CC 327. 1900 La Plata, Argentina

2 Department of Agronomy, Wageningen Agricultural University, Haarweg 333, $6709 \mathrm{RZ}$ Wageningen. The Netherlands

Accepted for publication: 5 January 1999

Additional keywords: yield limiting factors, yield reducing factors, seed potato. ware potato. cultivars, virus diseases, Solanum nuberosum L.

\section{Summary}

The potato is the most important horticultural crop in Argentina. Its commercial cultivation started in 1872/73 and production greatly increased due to area and yield increases. This paper surveys potato production in Argentina. It describes and quantifies distribution of crop area and production and the agro-ecological conditions in each growing area. Yield constraints are identified and a yield gap analysis was performed using the LINTUL-POTATO simulation model. Possibilities for further yield improvement are discussed. The survey established that important yield improvements were achieved in the country during the last 20 years. mainly due to the use of high quality seed. new cultivars, improved fertilizers and irrigation techniques, and better control of pests and diseases. However, the actual yield. at least for the regions studied, is still well below the attainable and potential yields established with the LINTULPOTATO model. Suggestions are made to improve further the potato yield in the different growing areas.

\section{Introduction}

Argentina is located in the southern region of South America, ranging from 22 to $56^{\circ}$ $\mathrm{S}$ and from 54 to $72^{\circ} \mathrm{W}$. It rises from sea level in the east to the high Andean mountains in the west to a maximum of about $7000 \mathrm{~m}$. The magnitude and diversity in altitude of the country accounts for the occurrence of many different climatic zones (BWk, BS, Cfa, Csb and ET, according to the Köppen classification. (Petterssen. 1976)) where many different crops can be grown, including maize. sorghum, wheat, sunflower, soybean, flax and many forage and horticultural crops. Table 1 shows the land distribution, acreage and production of some crops; among the horticultural crops. potato is the most important (INTA Balcarce, 1980).

Although there is evidence that during the Inca period the Indians grew potatoes in the Andean valleys of northwestern Argentina (L. Lanfranconi, personal communication, 1998), the first record of potato cultivation is from $1872 / 73$ with an area of 2361 ha (Caldiz, 1994). The crop was started in the area of the current city of Santa Fe (SL 31 ${ }^{\circ} 23^{\prime}$ ) and later it spread towards the southeast of the Buenos Aires province where the first crops were planted in 1886 with $\mathrm{cv}$. Violeta, named after its violet skin colour (Anon., 1954). Later, other cultivars derived from introductions from the USA and Europe were grown, such as Tomatera (1911) from Germany, 
Table 1. Land use and area and production of different crops in Argentina

\begin{tabular}{lcc}
\hline Land use $^{\mathrm{a}}$ & Area & \\
Total area & $3761274 \mathrm{~km}^{2}$ & \\
Continental area & $2791810 \mathrm{~km}^{2}$ & \\
Cultivated area & $29300000 \mathrm{ha}$ & \\
Forest woodland and natural forest & $63300000 \mathrm{ha}$ & \\
Natural and other grazing land possible to cultivate & $131100000 \mathrm{ha}$ & \\
Non-farming area (mountains, rivers, lakes, etc.) & $49000000 \mathrm{ha}$ & \\
\hline Crop & Area & Production \\
& (ha) & (000 tonnes) \\
Wheat & 7344000 & 15983 \\
Maize & 3926000 & 14496 \\
Soybean & 6648000 & 11013 \\
Sunflower & 3048000 & 5021 \\
Sorghum & 802000 & 2552 \\
Potato & 101733 & 2275 \\
\hline
\end{tabular}

a Data from Ediciones Aguilar (1992) and b from SAGPyA (1997).

Redonda (1915) derived from the American cv. Early Rose, Blanca (1915) from cv. White Rose and Chaqueña (1925) derived from Spaulding Rose. The latter two cultivars disappeared in 1935/36 due to severe virus infection (Sívori, 1951) and also because of the lack of interest from commercial growers (Anon., 1954).

By that time the introduction of seed from different cultivars was very important. Munck (1940) reported results of 59 cultivars grown in the period 1935/36-1939/40 at different locations. Mendiburu (1986) considered that the history of the production of seed potatoes in Argentina can be divided into four periods: (1) beginning of crop production in the late 1800s-1936: local seed production with local or imported cultivars; (2) 1937-1955: only imported seed used; (3) 1955-1985: use of both local and imported seed; (4) 1985-present: self-sufficiency. Currently, the use of imported seed is restricted to initial introductions of those cultivars required by the food processing industry that are not available in the country. For further information the reader is referred to Caldiz et al. (1999) who recently discussed the evolution of the seed potato production system in Argentina.

Although several authors have discussed the potato production situation in Argentina (Mendiburu \& Lucarini, 1980; Anon., 1989; Haverkort \& Caldiz, 1994; Huarte \& Inchausti, 1994; Huarte, 1996), no attempts have been made to analyze for each potato producing area the agro-ecological conditions that may determine, limit or reduce yield. Caldiz (1983) discussed several factors that could affect production but referred to seed crops exclusively. He concluded that among other production factors, the use of fertilizers and irrigation, planting dates, seed degeneration rate, distance to the ware production zones and presence of pests and diseases were important. However, in the period 1983-1996 circumstances changed considerably 
and both ware and seed potato production systems merit a renewed and comprehensive analysis to identify future possibilities for yield improvement. Moreover, in a recent national workshop it was recognized that the degree of importance of factors limiting and/or reducing growth and yield in the different regions needs to be identified and the yield reduction caused by these factors needs to be quantified (Huarte, 1994). Hence, the purpose of this paper is to analyze actual potato production in Argentina. It considers: (1) acreage and production in different areas; (2) agro-ecological conditions in each of these areas; (3) identification of yield constraints; (4) a yield gap analysis using the LINTUL-POTATO simulation model (Kooman \& Haverkort, 1995) for certain production areas and (5) possibilities for further yield improvement.

\section{Materials and methods}

Although the survey was carried out during 1994/95, all statistics in this paper are the latest ones available. The data on area, production and yield were obtained from the Secretary of Agriculture (SAGyP, 1995. SAGPyA, 1997), FAO (FAO, 1995) or were provided by several local sources from different provinces, such as INTA Extension Agencies and Experimental Stations belonging to each province (J. Ortego, personal communication. 1994; N. Zamudio, personal communication, 1994; Lanfranconi, 1994). These are presented in tables or figures, and when relevant, differences between sources are discussed. Soil data were obtained from the Secretary of Agriculture Soil Maps (SAGyP, 1989; 1990) and soil classification was done according to the Soil Survey Staff (1992). Long term meteorological data were obtained from the National Meteorological Service (Servicio Meteorológico Nacional, 1992) and from FAO (FAO, 1990). These data were used to characterize the agro-ecological conditions of each area.

The identification of different factors influencing yield was based on either local and current information or previous publications, as quoted in the following sections. In potato, as in other crops, yield is determined or defined by various factors which were grouped according to Penning de Vries \& Rabbinge (1995). Daylength, incoming radiation, temperature, carbon dioxide concentration and cultivar are Yield Defining or Determining Factors (YDF's) and the potential yield of a crop depends on them. Water and nutrients are Yield Limiting Factors (YLF's) that can be modified by growers through cultural practices, such as application of inputs, and so determine the gap between potential and attainable yields (Fig. 1). Diseases, weeds and pests are considered Yield Reducing Factors (YRF's) and consequently lead to lower yield when they are present; these factors determine the gap between attainable and actual yields. For each production area the main YDF's, YLF's and/or YRF are mentioned and, when relevant, strategies to improve yield are discussed.

A yield gap analysis was performed with the LINTUL-POTATO simulation model (Kooman \& Haverkort, 1995) using daily global radiation, minimum and maximum temperature from FAO (FAO, 1990) and Servicio Meteorológico Nacional (1992) databases. The model establishes potential yield of a certain cultivar for a determined 


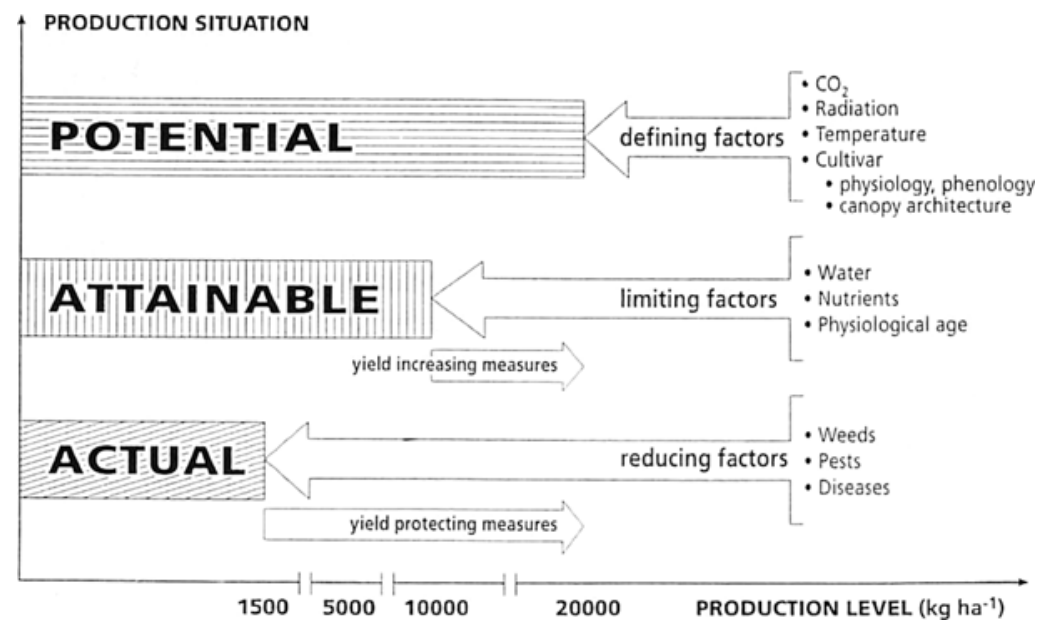

Fig. 1. Overview of actual, attainable and potential yield levels in relation to reducing. limiting or defining yield factors. Modified from Penning de Vries \& Rabbinge (1995).

growing period and plant density, assuming that there are no YLF's or YRF's present and that crop growth does not take place when minimum temperatures are below 5 ${ }^{\circ} \mathrm{C}$ and maximum temperatures are above $28^{\circ} \mathrm{C}$. Model simulation is based on: (a) incident Photosynthetically Active Radiation (PAR, 400-700 nm); (b) fraction of PAR intercepted by the crop and (c) radiation use efficiency (RUE) to produce dry matter. Phenological crop development is driven by accumulated temperature, while development stage determines dry matter partitioning and, through haulm growth, the pattern of intercepted PAR is defined. The model simulates the interception of radiation from the time of $50 \%$ emergence through to senescence. Radiation use efficiency (RUE) was set at a constant value of $2.8 \mathrm{~g} \mathrm{MJ}^{-1}$ based on the results of Echeverría et al. (1992) and Saluzzo (1994) for Argentinian conditions. For dry matter distribution, tuber yields equal the product of total biomass produced and the harvest index (HI). The $\mathrm{HI}$ is derived from the average temperature during tuber growth. In potatoes more dry matter is distributed to the haulm with increasing temperatures (Midmore, 1990), then up to $15^{\circ} \mathrm{C}$ the $\mathrm{HI}$ remains constant at 0.8 and decreases at higher temperatures to reach 0 at $28^{\circ} \mathrm{C}$ (Stol et al., 1991). A study of the data for five different regions was carried out and data from the model were compared with the actual and attainable yields to perform a yield gap analysis and make further suggestions for yield improvement.

\section{Results and discussion}

Area, production and yield in the country

Since the beginning of the crop in the late $1800 \mathrm{~s}$, the area markedly increased to over 200,000 ha during the 1950 s. In the following 20 years it decreased by more than $50 \%$ 
and later stabilised around 120,000 ha. At present the cropping area is 102,000 ha (Fig. 2a). The production markedly increased to almost 2.8 million tonnes during the 1980 s due to constant increases in tuber yield per hectare (Fig. 2b). During the period 1872-1922 tuber yield was almost constant, while in the period 1934-1994 it increased by over $250 \mathrm{~kg} \mathrm{ha}^{-1} \mathrm{yr}^{-1}$. During the period 1934-1990 the average yield increased by $61 \mathrm{~kg} \mathrm{ha}^{-1} \mathrm{yr}^{-1}$ for the world and 365 and $144 \mathrm{~kg} \mathrm{ha}^{-1} \mathrm{yr}^{-1}$ for North and South America, respectively. For Asia and Africa values were 124 and $60 \mathrm{~kg} \mathrm{ha}^{-1} \mathrm{yr}^{-1}$ respectively (Caldiz, 1994). Clearly, tuber yields in Argentina increased much faster than the averages for the world, Asia, Africa and South America. Yield improvement during the 1980 s can be attributed to the introduction of new cultivars, application of fertilizers and irrigation, and increased control of late blight (Phytophthora infestans) in the major growing areas (Mendiburu \& Lucarini, 1980). More recently, further
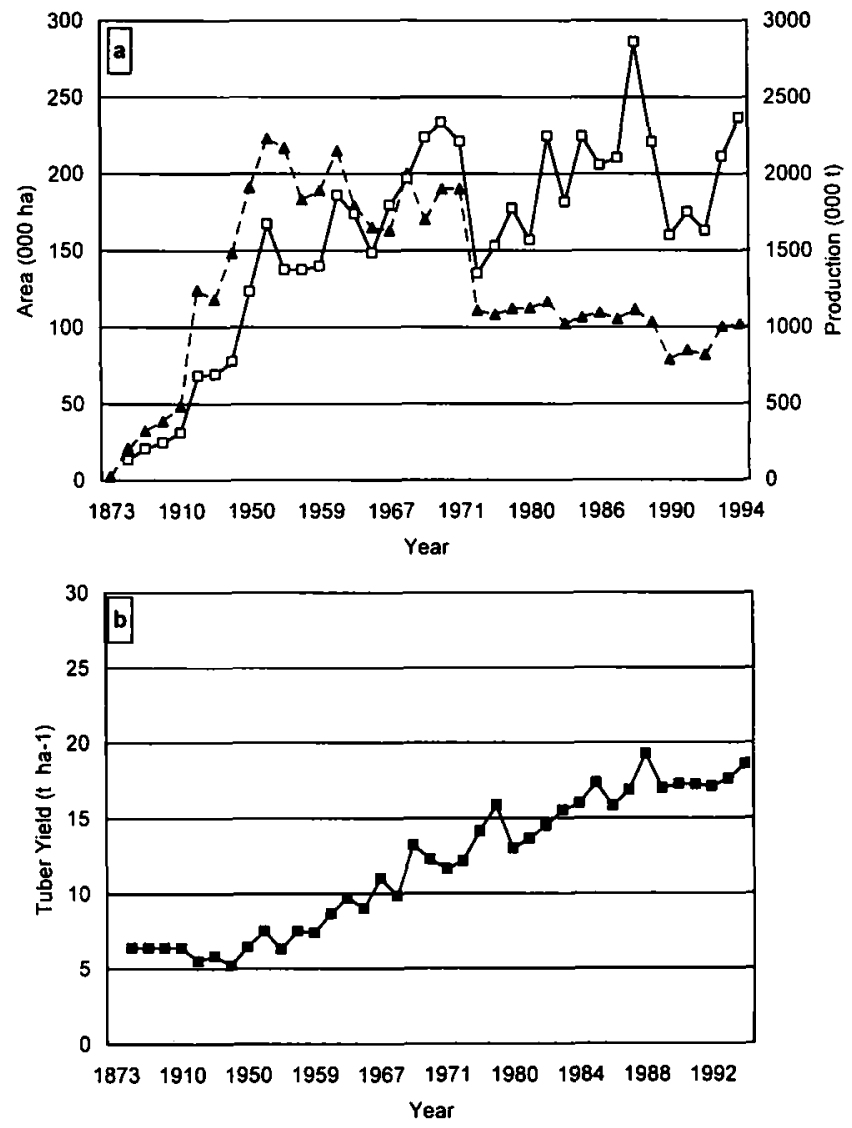

Fig. 2. (a) Evolution of area (A), production $(\square)$ and (b) tuber yield ( $\square$ ) in Argentina during the period 1873-1994. Note that the $\mathrm{x}$-ases are not linear. 
yield increases were obtained by the use of virus-free seed and the introduction of new, high-yielding cultivars (Escarrá, 1989; Caldiz \& Beltrano, 1992).

Despite these yield increments, the national average yield of $20.3 \mathrm{t} \mathrm{ha}^{-1}\left(22.8 \mathrm{tha}^{-1}\right.$ for 1995/96, according to recent data from the Secretary of Agriculture (SAGPyA, 1998)), is far below the potential yield of the crop for the different regions. For example, in the southeast region of the Buenos Aires province, which by 1993/94 accounted for $40 \%$ of the total potato acreage (SAGyP, 1995), the average yield is $27.3 \mathrm{t} \mathrm{ha} \mathrm{A}^{-1}$, while the potential yield, estimated according to van der Zaag \& Burton (1978) is $88 \mathrm{t} \mathrm{ha}^{-1}$ (Cantos de Ruiz, 1988). These and other yield differences will be analyzed in detail in the following pages.

\section{Area, production and yield in the main potato growing provinces}

Seed and ware potato growing areas. Seed crops are grown during the summer from October/November to February/March, either in highland valleys such as Tafí del Valle, Tucumán; Las Estancias, Catamarca; Sierras Grandes, Córdoba and Malargüe, Mendoza, or in coastal areas (Fig. 3), such as the southeast of the Buenos Aires province (Haverkort \& Caldiz, 1994) and Tierra del Fuego Island (Caldiz et al., 1999). The cropping area varies from 200 to 1,500 ha in different locations but tuber yields are quite similar in all cases (Table 2). Probably early haulm killing that is practised in this crop is responsible for this situation. Haulm killing is not common in the ware crop.

Table 2. Seed potato growing provinces in Argentina. Growing perioda, area, production, average yield and potato cultivars used.

\begin{tabular}{|c|c|c|c|c|c|c|}
\hline Province & Location & $\begin{array}{l}\text { Growing Period } \\
\text { JASOND/JFM AM J }\end{array}$ & $\begin{array}{l}\text { Area } \\
\text { (ha) }\end{array}$ & $\begin{array}{l}\text { Production } \\
\text { (t) }\end{array}$ & $\begin{array}{l}\text { Yield } \\
\left(\mathrm{t} \mathrm{ha}^{-1}\right.\end{array}$ & $\begin{array}{l}\text { Cultivars } \\
\text { 1) }\end{array}$ \\
\hline Tucumán ${ }^{b}$ & Tafí del Valle & & 500 & 12500 & 25.0 & $\begin{array}{l}\text { Spunta } \\
\text { Bintje }^{c}\end{array}$ \\
\hline Catamarcab & Las Estancias & & 1500 & 37500 & 25.0 & $\begin{array}{l}\text { Spunta } \\
\text { Kennebec }\end{array}$ \\
\hline Córdobae & Sierras Grandes & & 500 & 12500 & 25.0 & Spunta \\
\hline Mendoza ${ }^{f}$ & Malargüe & & 1000 & 19250 & 19.2 & Spunta ${ }^{\mathrm{f} g}$ \\
\hline Mendoza $f$ & Tupungato & & 266 & 5320 & 20.0 & Spunta \\
\hline Mendozaf & Uspallata & & 207 & 4347 & 21.0 & Spunta \\
\hline Buenos Aires $^{h}$ & Southeast & & 1500 & 31785 & 21.1 & Spunta ${ }^{h}$ \\
\hline \multicolumn{3}{|c|}{ Total area, Total production, Average yield } & 5473 & 123202 & 22.32 & \\
\hline
\end{tabular}

a All seed crops belong to the medium late type and are grown during summer (southern hemisphere). ${ }^{b}$ From: N. Zamudio, personal communication, 1994. c Data from Orell (1990), other cultivars: Jaerla, Russet Burbank, Achat. d Data from Anon. (1989), other cultivars: Jaerla, Mona Lisa, Huinkul, Ballenera. ' From: L. Lanfranconi, personal communication, 1998), other cultivars: Kennebec and Bintje. ${ }^{f}$ From: J. Ortego, personal communication, 1994. g Data from Anon. (1989), other cultivars: Kennebec, Huinkul, Pentland Crown, Mailén INTA. " Data from Anon. (1989), other cultivars: Ballenera, Kennebec, Huinkul, Chacay INTA, Frital INTA, Mailén INTA, Pampeana INTA, Primicia INTA, Russet Burbank, Shepody, Bright, Cardinal, Empire, Escort. 


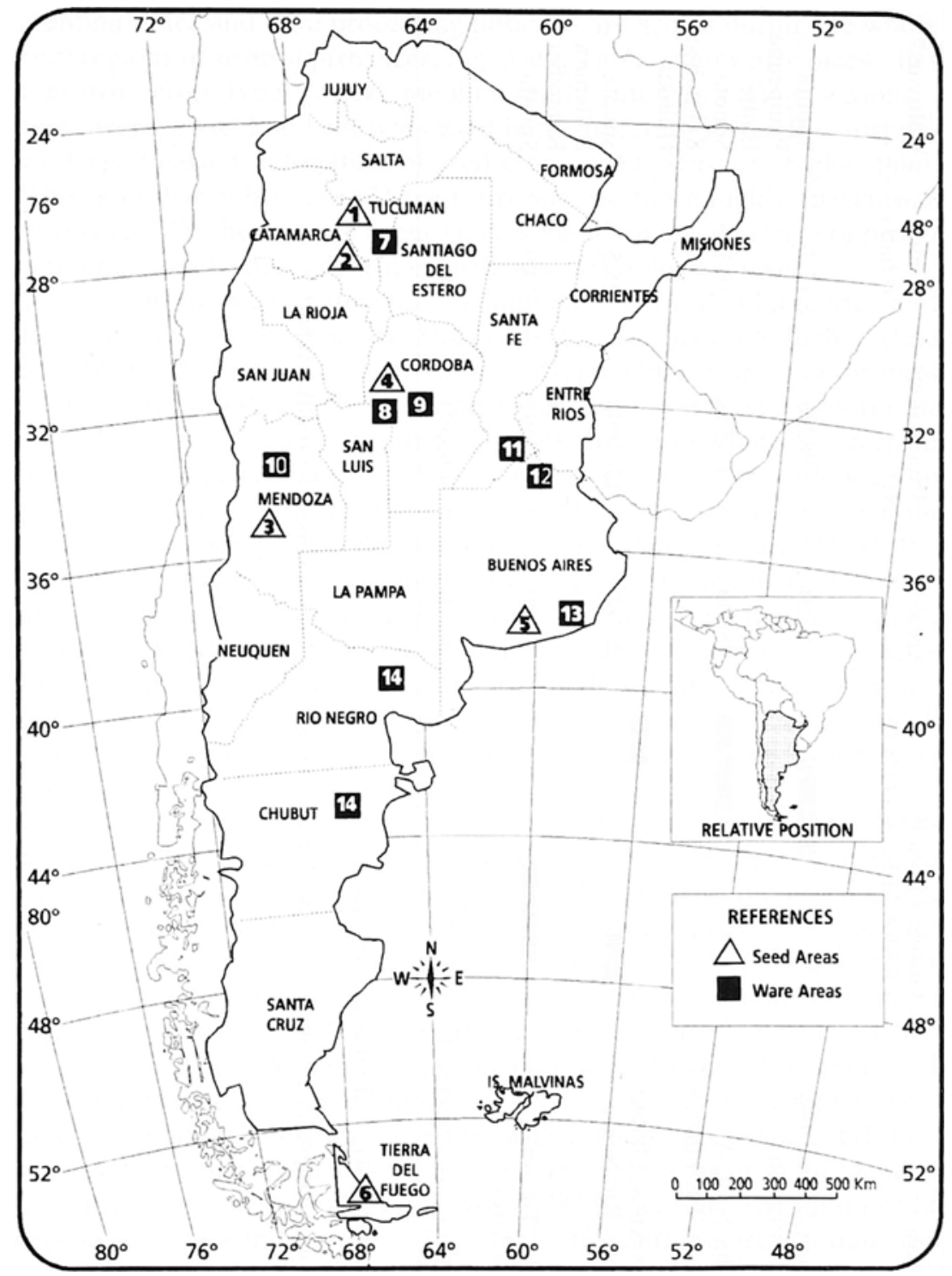

Fig. 3. Location of seed and ware potato growing areas in Argentina.

References: Seed $(\Delta)$ and ware $(\square)$ areas.

Seed areas: (1) Tafí del Valle; (2) Las Estancias; (3) Malargüe: (4) Sierras Grandes; (5) southeast of Buenos Aires: (6) Tierra del Fuego.

Ware areas: (7) Concepción and Morteros, early; (8) and (9) Villa Dolores and Córdoba horticultural belt, respectively, medium early and late; (10) Tupungato and Uspallata, medium-early and medium-late; (11) and (12) Santa Fe and northeast of Buenos Aires, respectively, medium early and late: (13) southeast of Buenos Aires and (14), Rio Negro and Chubut, respectively, medium-late. 
D.O. CALDIZ AND P.C. STRUIK

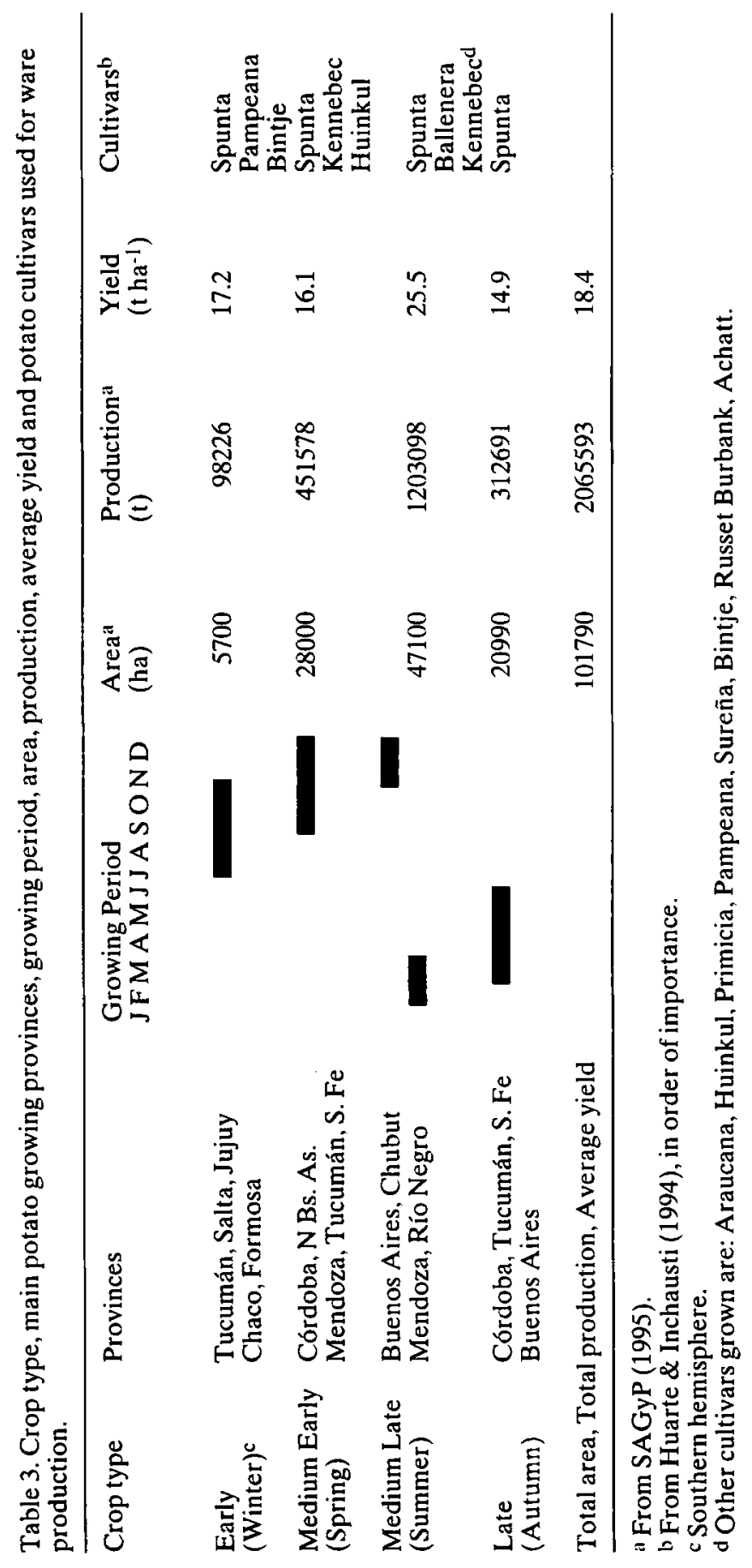


In Argentina, ware and food processing potatoes are grown during the whole year in different regions of several provinces. Fig. 3 and Table 3 show provinces where the crop is grown, crop type (early, medium early, etc.), growing seasons, area, production, average yield and cultivars used in the different areas. It is surprising to note that despite earlier defoliation of seed crops, seed yields are higher than ware yields. This is probably because (1) seed growers are more highly specialised than ware growers and (2) the average tuber yield is based on a wide range of production levels including those from small farmers with low technological level.

The most important ware crop is the medium late one, with a large area and high production and yield in the Buenos Aires province. In this crop. higher yields are obtained than in other regions. These results differ slightly from those proposed by Huarte \& Inchausti (1994) for the different zones, but nevertheless confirm that the average yield for the country is around $20 \mathrm{t} \mathrm{ha}^{-1}$. In the medium late crop several cultivars are grown. According to the most recent reference (Rodriguez Quijano, 1989 ) the distribution of cultivars in the mid-late 1980s was: Spunta (32\%), Ballenera MAA (29\%), Kennebec (14\%), Huinkul (10\%) and other cultivars (15\%). In other areas, Spunta is by far the most dominant cultivar. However, the increased interest in processing means that the area of other cultivars with higher dry matter content, such as Russet Burbank, Atlantic, Frital INTA and Shepody, will expand at the expense of cv. Spunta. During the last fifteen years the medium early and late crops have significantly increased, especially in the Córdoba province where at present 14.200 and 19,500 ha are grown for the medium early and late crops, respectively (L. Lanfranconi, personal communication, 1998).

Area, production and yield for the main potato producing provinces for 1980-1994 are shown in Fig. 4 . In this period the area in Buenos Aires decreased by more than $40 \%$ and total production by a similar proportion. Tuber yields increased at a rate of $800 \mathrm{~kg} \mathrm{ha}^{-1} \mathrm{yr}^{-1}$; the 1994 average yield of $27.3 \mathrm{t} \mathrm{ha}^{-1}$ for the province is the country's highest (Figs $4 a$ and $b$ ), while recent data established the average yield for the province at $31.04 \mathrm{t} \mathrm{ha}^{-1}$ (SAGPyA, 1998). Córdoba is the second most important potato producing province in the country, and in the period considered the area increased by more than $165 \%$ and the production by $356 \%$ (Fig. $4 \mathrm{c}$ ), associated with an increase in tuber yield per ha of more than $72 \%$ at a rate of $453 \mathrm{~kg} \mathrm{ha}^{-1} \mathrm{yr}^{-1}$ (Fig. 4d). Sandy soils allow production of tubers with a good appearance and thus high price in the market which enhances the growers' interest in the crop. In Mendoza the area was reduced but due to a yield increase of $282 \mathrm{~kg} \mathrm{ha}^{-1} \mathrm{yr}^{-1}$ the total production was higher in the 1990s than in 1980 (Figs 4e, f). In Santa Fe area, production also decreased by more than $40 \%$ while yields per hectare have levelled off since 1989 . An increase of $92 \mathrm{~kg} \mathrm{ha}^{-1} \mathrm{yr}^{-1}$ was recorded over the entire period considered (Figs $4 \mathrm{~g}$ and $h$ ). The severe reduction in yield and production in 1981 was attributed to the spread of Pseudomonas solanacearum, favoured by the double cropping system and by high temperatures (A. Escande, personal communication, 1981). In Tucumán, a province characterized by its early production during the winter, area and production increased (Fig. 4i) while tuber yields per hectare increased by $374 \mathrm{~kg} \mathrm{ha}^{-1} \mathrm{yr}^{-1}$ when data from 1980 with unusually high yields for that time are excluded (Fig. 4j). 


\section{D.O. CALDIZ AND P.C. STRUIK}
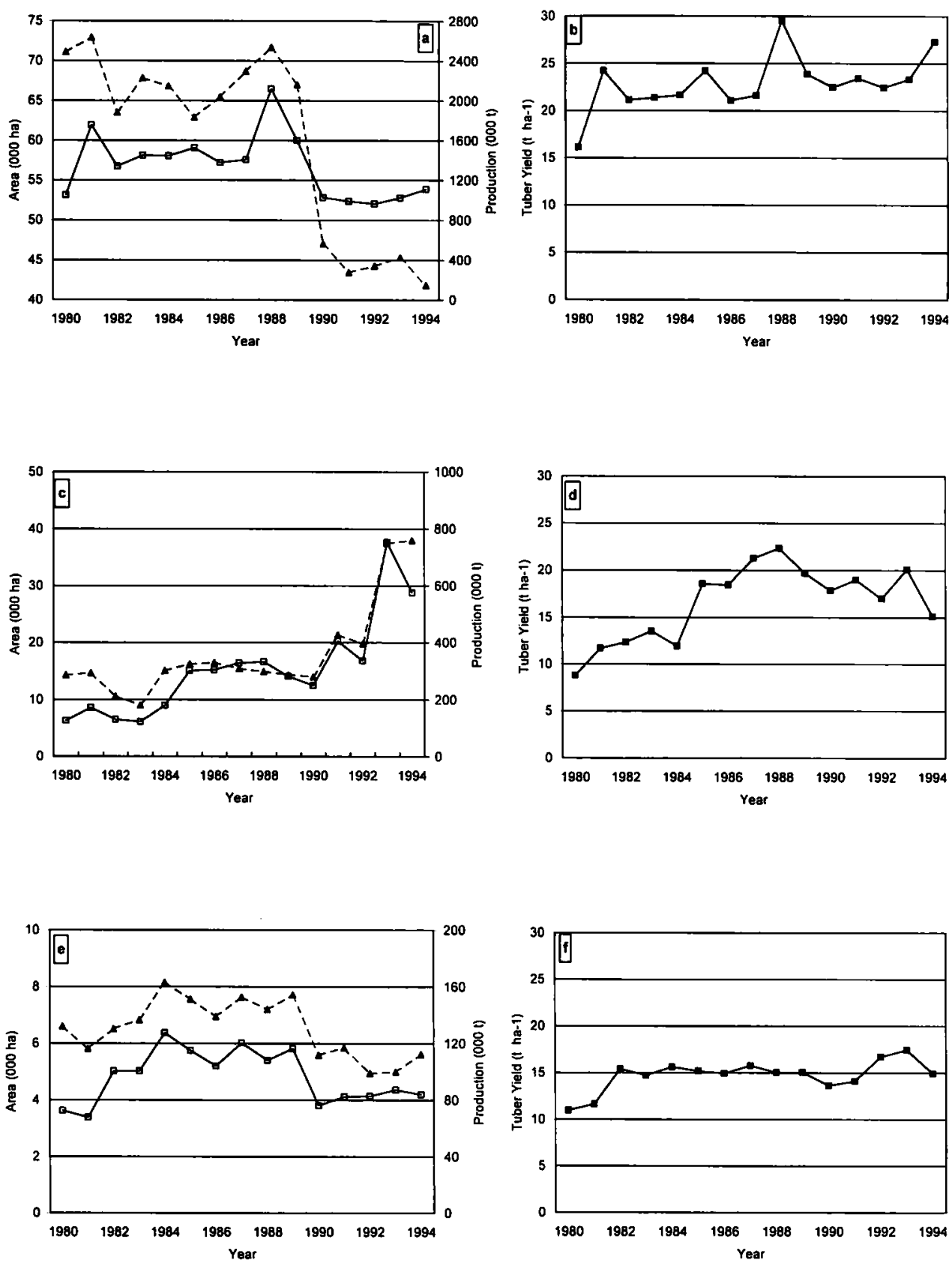

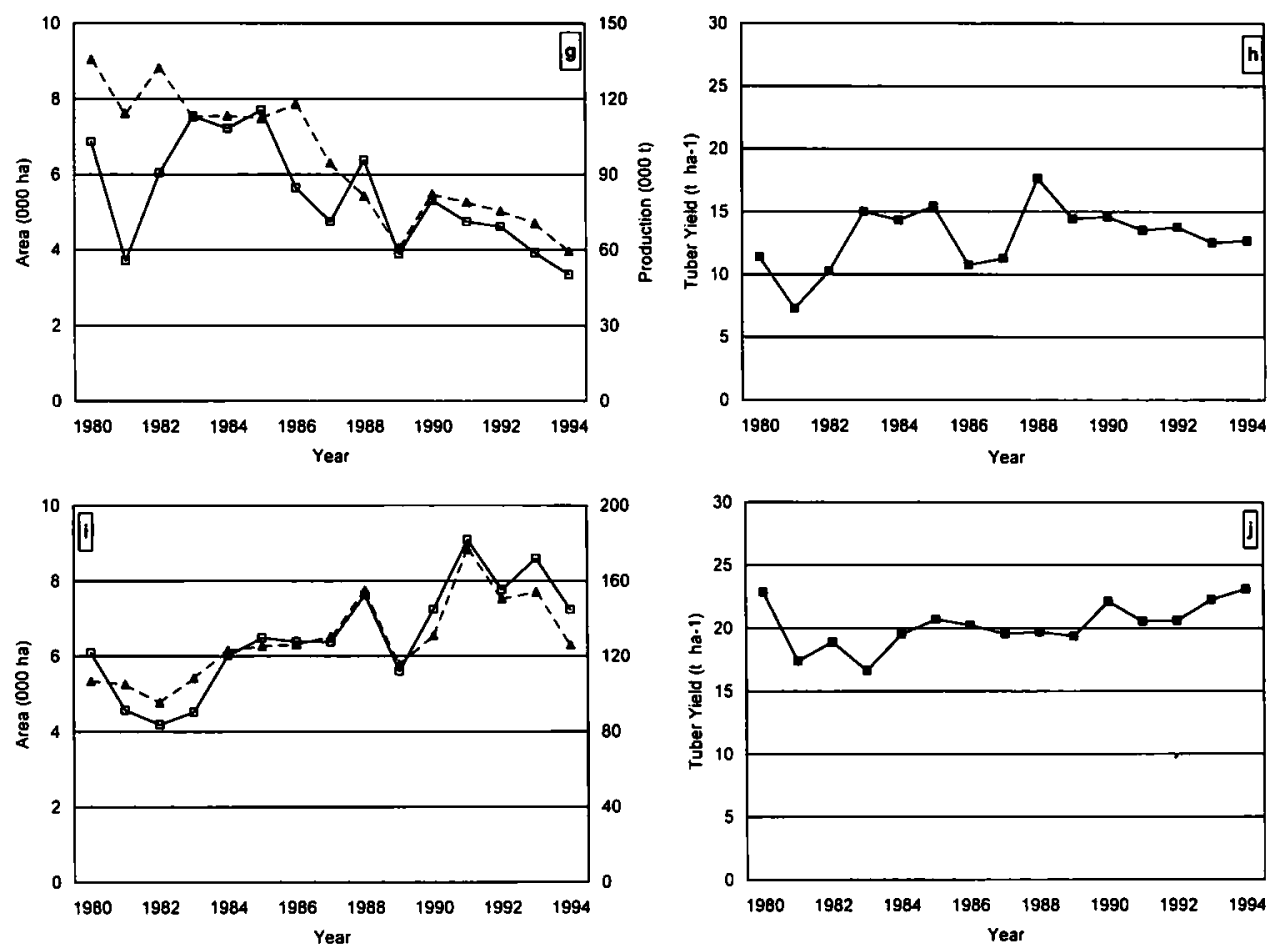

Fig. 4. (a) Evolution of area ( $\Delta$ ). production $(\square)$ and (b) tuber yield ( $\square$ ) in the most important potato producing provinces during the period 1980-1994.

References: ( $a$ and b) Buenos Aires; ( $c$ and d) Córdoba; (e and f) Mendoza: ( $g$ and $h$ ) Santa Fe and ( $i$ and $j$ ) Tucumán.

Agro-ecological characteristics of the seed and ware areas and possible yield constraints

An overview of soil characteristics is given in Table 4. For simplicity the characteristics of the areas and the possible yield constraints will be analyzed for each province, for the seed and ware crops separately, and only the most conspicuous and most important cases will be discussed.

\section{Seed areas}

As mentioned, a detailed description of the seed potato production system in Argentina is presented elsewhere (Mendiburu, 1986; Caldiz et al., 1999); nevertheless some relevant aspects are also considered in this paper.

Tafi del Valle, Tucumán. The area was developed during 1970-975 and approved as seed area in 1976 (Rojas et al., 1975; 1979). It is located at $2000 \mathrm{~m}$ above sea level and shows Monsoon type climate, with heavy rains occurring during January-February. Main YLF is water availability during part of the growing season, whereas YRF's are severe attacks 
D.O. CALDIZ AND P.C. STRUIK

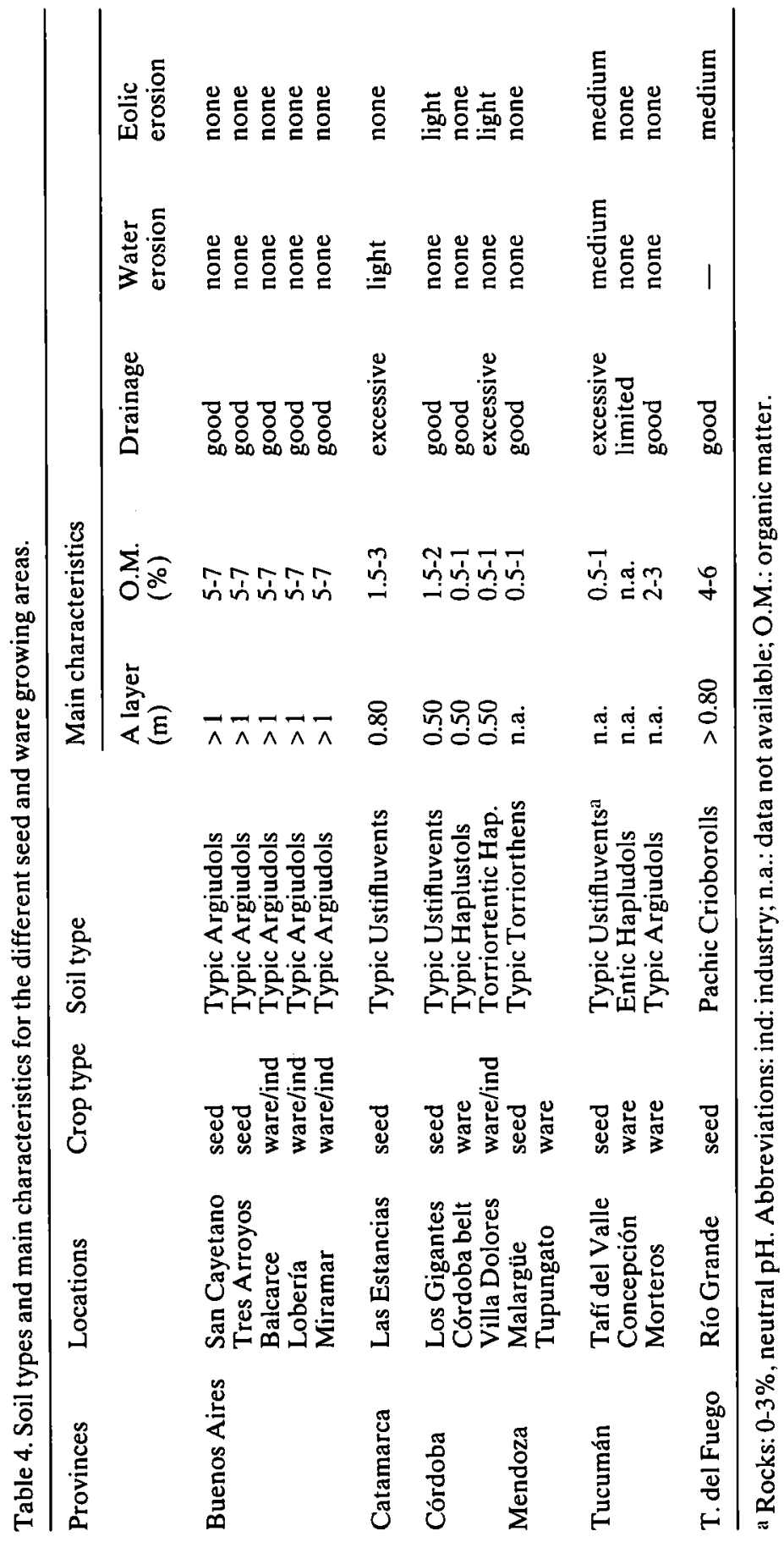


of late blight ( $P$. infestans) and Rhizoctonia solani. The average yield is $25 \mathrm{t} \mathrm{ha}^{-1}$.

Las Estancias, Catamarca. The valley is located in the area of El Pucará in the Aconquija Mountains at 1,400-1,660 m above sea level. Two thousand hectares can be cultivated from the 24,000 ha that form the Pucará. Ground water of high quality is available for irrigation. The area was developed by potato growers from the area of Concepción, Tucumán. It has different accesses, either from Concepción $(90 \mathrm{~km})$, Catamarca city $(160 \mathrm{~km})$ or Andalgalá $(120 \mathrm{~km})$. Fifteen hundred hectares are cultivated with seed potatoes during the summer period (October-March). Main YLF's are water availability during part of the growing season and unsuitable physiological age of the seed, while the occurrence of aphid flights and severe attacks of late blight ( $P$. infestans) are major YRF's. The average yield is $23 \mathrm{tha}^{-1}(\mathrm{~N}$. Zamudio, personal communication, 1994).

Malargüe, Mendoza. Malargüe valley is located in the SW of the province at $1,400 \mathrm{~m}$ above sea level and was recognized as a seed potato producing area in 1982 (Chiarlo, 1996). Rivers originating in the Andean Mountains provide good quality water for irrigation for an area of 4,000 ha. Potato crops are grown during the summer (October-March) in an area of 1,000 ha with an average yield of $19.5 \mathrm{tha}^{-1}$. The main YDF is the dry, hot and persistent "zonda" wind that reduces the relative humidity to less than $15-20 \%$. The main YLF is the physiological age of the seed due to inadequate storage (J. Ortego, personal communication, 1994) and the main YRF's are $R$. solani, Fusarium spp., Streptomyces scabies and the presence of Meloidogyne spp. in some fields (Ortego, 1996).

Sierras Grandes, Córdoba. This is a new area of 500 hectares where healthy seed potatoes can be grown, but not much information is available about it. In this area potatoes are grown between $1,100-2,100 \mathrm{~m}$ above sea level in Yacanto de Calamuchita, Pampa de Achala. Pampa de San Luis, Pampa Olaen and Pampa del Pocho (L. Lanfranconi, personal communication, 1998). Another seed area is located to the north of Sierras Grandes in Ongamira (1,100-1,300 $\mathrm{m}$ above sea level). The seed can be used for the medium early crop planted in the "horticultural belt" of Córdoba and the Villa Dolores area with minimum costs of transport. In the future, lack of storage facilities in the area might become a problem.

The Southeast of the Buenos Aires Province. At present seed potatoes are grown in San Cayetano and Tres Arroyos counties where sea-winds are prevailing. Annually, 1,400 ha of seed potatoes are grown with an average yield close to $30 \mathrm{t} \mathrm{ha}^{-1}$. Good soil quality (Table 4) and favourable environmental conditions enhance the production of high yielding crops. The area is one of the leading areas regarding technological development; progress was recently enhanced due to demands from the potato processing industry concerning the use of new cultivars and seed quality. Better efficiency of water and fertilizer use could probably improve average yield. A YRF concerning seed potato health is the occasional presence of different aphids 
responsible for virus transmission.

Tierra del Fuego Island. This is an isolated area in the southern part of the country with a characteristic oceanic cold climate. Occidental and persistent winds are predominant in the Magallanic Steppe, an arid environment, where only 10 ha have been grown in the "José Menéndez" farm. A recent paper by Caldiz et al. (1999) demonstrated, after three years of research, that the area is free from nematodes and the aphid population is very low. Crops must be grown from mid October-January in order to escape frosts. Main YDF's are long days during the summer period which delay tuber initiation, and risk of frost during the growing period. In the Rio Grande area the persistent west wind damages foliage and the limited rainfall, less than $300 \mathrm{~mm} \mathrm{yr}^{-1}$, reduces crop growth. The use of pre-sprouted and physiologically old seed is a pre-requisite to achieve acceptable tuber yield in such a short growing season and no YRF's have been identified. The results of Caldiz et al. (1999) indicated an average yield of $22 \mathrm{tha}^{-1}$.

During the period 1960-1985 cvs Huinkul MAG and Ballenera MAA accounted for more than $80 \%$ of the Argentinian market. These cultivars have a long absolute dormant period (Caldiz, 1994) which allows them to be stored in "heaps in the field". The situation changed when cv. Spunta was introduced, because seed tubers of this cultivar must be stored at $2-4{ }^{\circ} \mathrm{C}$ to reach the new planting season with a suitable physiological age (Caldiz et al., 1984, 1996). Hence refrigerated, and refrigerated and forced ventilated stores were developed. Seed storage capacity in refrigerated stores is 37,450 tonnes while in stores with refrigeration and forced ventilation it is 40,850 tonnes (Caldiz, 1996). However, this capacity is being continually and permanently increased, particularly because many growers build their own stores.

\section{Ware areas}

Tucumán. In this province, ware production is mainly carried out at the sites of Concepción, Morteros, Aguilares and Famaillá at an altitude $300-600 \mathrm{~m}$ above sea level. Local informers estimated yield to be approximately $16 \mathrm{t} \mathrm{ha-1}$. Three crops are grown: early (June-October), medium early (August-December) and late (February-June). In the early planting the YDF is the length of the growing season which is reduced by low temperatures at planting and high temperatures and heavy rains at harvest. For this crop, the YLF is the physiological age of the seed produced in the mountains (Tafí del Valle, Tucumán) in the medium late crop (October-March); the seed is too young to be used successfully for the early crop. A breeding programme carried out by INTA and the Obispo Colombres Experimental Station is trying to obtain new cultivars with a short absolute dormant period and early sprouting (Huarte, 1989). For the medium early crop the main YDF is the occurrence of heavy rains at harvest which shorten the growth cycle and consequently reduce tuber yield and the main YRF is the occurrence of $P$. infestans. Therefore, average yields for the ware crop were only $15.6 \mathrm{t} \mathrm{ha}^{-1}$ (N. Zamudio, personal communication, 1994) with a recent increase to $19.2 \mathrm{t} \mathrm{ha}^{-1}$ (SAGPyA, 1998).

Córdoba. This province is located in the semi-arid region of Argentina. The area 
surrounding the capital lies at $300-600 \mathrm{~m}$ above sea level and is known as the "horticultural belt" (HB). The area of Villa Dolores (VD) is at $600-900 \mathrm{~m}$ above sea level and soils are Torriortentic Haplustols from loessic origin, with eolic erosion during the winter dry period (C. Del Caso, personal communication, 1994). Both areas, the "horticultural belt" and Villa Dolores, produce potatoes in autumn and spring in a double cropping system typical of mediterranean areas (Fahem \& Haverkort, 1988). YDF's for this system are, for the late crop, long days and high temperatures at planting, and low temperatures and low irradiance at the end of the growing season which reduce tuber growth. For the medium early (spring) crop YDF's are short days at planting and high temperatures at the end of the crop and harvest, which cause severe losses in tuber quality and reduce storability of the tubers. YLF's for the late crop are use of physiologically young seed, which leads to variable emergence, a problem enhanced by the use of cut seed, and high temperatures at planting. In many cases whole potato fields must be re-planted (C. Del Caso, personal communication, 1994). Another limiting factor for the Villa Dolores area is the lack of arable land to improve crop rotation. The land use is currently dominated by rotations of winter cereals and grasslands and in Colonia Tirolesa located in Córdoba "horticultural belt" around 4,000 ha of potatoes are planted without irrigation within this rotation ( $L$. Lanfranconi, personal communication, 1998). Clearance of new land in Villa Dolores area is expensive and therefore the frequency of potato growing on the same piece of land is high. In many fields two potato crops are planted in the same field per year. YRF's are limited to the presence of Meloidogyne spp. (VD), the perennial weeds Sorghum halepense (VD) and Cyperus rotundus (HB), $R$. solani in the medium early crop and bacterial diseases in the late crop and to normal attacks of Alternaria solani and $P$. infestans. The average potato yields are 25 and $18 \mathrm{tha}^{-1}$ for the spring and autumn crop respectively (C. Del Caso, personal communication, 1994), but for the late crops attainable yields of $40 \mathrm{t} \mathrm{ha}^{-1}$ have been achieved (Caldiz et al., 1997).

Mendoza. This province is located in the western region of the country in the area of the Andean Mountains. Ware crops are planted in two areas, Tupungato and Uspallata, in three different seasons: a medium early (August-December) and a medium late cropping season (December-March) in the lowlands of the area and an intermediate cropping season (October-January) in the highlands. Average yields for both zones are $20 \mathrm{t} \mathrm{ha}^{-1}$ (J. Ortego, personal communication, 1994). The main YLF is physiological age of the seed due to lack of adequate storage systems. Storage in heaps in the field produces poor results, mainly with cv. Spunta which is sensitive to physiological aging (Caldiz et al., 1984). Cold stores available are designed for fruits (apples, pears) and not for potatoes. Another YLF is the narrow rotation with nutrient demanding crops such as carrot, garlic and onion.

Buenos Aires. The main area for potato production is located in the southeast region of the province between the mountain systems of Tandil and Ventania. The crop is grown during the summer period (October-March) and belongs to the medium-late type, as in other regions such as Mendoza, Chubut and Río Negro. Probably one of 
the main factors limiting yield is the physiological age of the seed, either because it is inadequately stored or because it comes from different origins (Caldiz et al., 1984; Caldiz, 1991; Caldiz \& Fernández, 1995). Another factor is the inefficient use of irrigation water. High temperatures during harvest (February-March) may occasionally reduce tuber quality and the shortage of storage capacity for the seed of early sprouting cultivars, such as Spunta and Kennebec, increases storage losses (Escande et al., 1985; 1986). In this area vertical soil tillage and the use of crop residues to improve soil structure and keep soil moisture are increasing, while, due to the requirements of the food processing industry to avoid tuber greening, row distance is being modified to $0.85-0.95 \mathrm{~m}$ (Huarte, 1996). Huarte \& Inchausti (1994) quoted an average tuber yield for the area of $30 \mathrm{t} \mathrm{ha}^{-1}$.

Rio Negro and Chubut. In these two provinces potatoes are grown during the summer period in the valleys of Rio Negro and Chubut rivers. In Río Negro the crops are located around Choele Choel in the mid-valley. Sandy soils are suitable for potato production but they are low in organic matter and nutrient content and affected by wind erosion. Hence irrigation and fertilization management are crucial to achieve high yields. Due to daylength $(>18 \mathrm{~h}$ ), temperature amplitude and high irradiance, tuber dry matter percentages are higher than in other production areas. For example, in cv. Russet Burbank values of $23 \%$ DM were found while in other areas the average for this cultivar is around 20\%; under these conditions yields higher than $40 \mathrm{tha} \mathrm{h}^{-1}$ were achieved (D.O. Caldiz, unpublished). At present 350 ha are being grown for the processing industry (M. Inchausti, personal communication, 1998). Isolation of these areas also allowed seed production of specific cultivars that are exported to Brasil (Anon., 1998).

\section{Yield gap analysis}

The potential yield established with the LINTUL-POTATO simulation model (Kooman \& Haverkort, 1995) was used to perform a preliminary yield gap analysis regarding actual and attainable potato yield in different areas of the country. Table 5 shows the values of actual, attainable and potential yield for each of these areas. In

Table 5. Actual, attainable and potential yield of ware potato $\left(\mathrm{t} \mathrm{ha}^{-1}\right)$ at different Argentinian locations.

\begin{tabular}{llcc}
\hline Location & Actual & Attainable & Potential \\
Tucumán, Early crop & 18 & $30^{\mathrm{a}}$ & $68^{\mathrm{b}}$ \\
Mendoza, Medium-late crop & 20 & $35^{\mathrm{a}}$ & $65^{\mathrm{a}}$ \\
Rosario, Late crop & 13 & $25^{\mathrm{a}}$ & $55^{\mathrm{b}}$ \\
Villa Dolores, Medium-early crop & 25 & $45^{\mathrm{c}}$ & $55^{\mathrm{b}}$ \\
Villa Dolores, Late crop & 18 & $41^{\mathrm{d}}$ & $47^{\mathrm{b}}$ \\
Balcarce & 30 & 100 & $126^{\mathrm{b}} / 88^{\mathrm{e}}$ \\
\hline
\end{tabular}

a Estimated by the authors; ${ }^{b}$ Based on LINTUL-POTATO; ${ }^{c} \mathrm{C}$. del Caso, personal communication, 1998; d From Caldiz et al. (1997) and e From Cantos de Ruiz et al. (1988). 
the most important potato production areas, the southeast of the Buenos Aires province, the actual average yield of $30 \mathrm{t} \mathrm{ha}^{-1}$ is far below the $88 \mathrm{t} \mathrm{ha}^{-1}$ of potential yield calculated by Cantos de Ruiz (1988) based on van der Zaag \& Burton (1978) or the $126 \mathrm{t} \mathrm{ha}^{-1}$ potential calculated in this study with the LINTUL-POTATO model. Cantos de Ruiz (1988) attributed differences between actual and potential yield to suboptimal light interception by the foliage. Nevertheless, the best farmers have obtained more than $50 \mathrm{tha}^{-1}$ in the $1994 / 95$ season, mainly due to improved water and fertilizer management (Huarte, 1996). This probably enhances ground cover duration, by faster canopy development and a delay in leaf senescence, giving larger and longer maximum interception. Recently, Huarte \& Cacace (1998) also presented data on attainable yields of $100 \mathrm{t} \mathrm{ha}^{-1}$.

In Tucumán, a first approach with the LINTUL-POTATO model established a potential yield of $68 \mathrm{t} \mathrm{ha}^{-1}$ for the early crop, while the actual average yield is only $18 \mathrm{t}$ $\mathrm{ha}^{-1}$ due to the poor physiological status of the seed used (Table 5). For Mendoza with crops growing in the period October-February the potential yield based on LINTULPOTATO was $65 \mathrm{t} \mathrm{ha}^{-1}$, while the actual average is $20 \mathrm{t} \mathrm{ha}^{-1}$ (Table 5). Probably the use of seed of unsuitable age and inadequate crop management are partially responsible for these differences. In Rosario, the late crop has a potential yield of $55 \mathrm{t}$ $\mathrm{ha}^{-1}$, but the actual yields of $13 \mathrm{tha}^{-1}$ are less than $25 \%$ of the potential. This is caused by a combination of factors among which are poor seed management, inadequate physiological age of the seed, and suboptimal management of water and fertilizer.

In Villa Dolores potential yields are 55 and $37 \mathrm{t} \mathrm{ha}^{-1}$ for the spring and autumn crops, respectively, while the actual average yields for these seasons are 25 and $18 \mathrm{t}$ $\mathrm{ha}^{-1}$, respectively. In this area a much larger proportion of the potential is realized. The role of different YDF's and YLF's for each of these crops was discussed previously, and recently Caldiz \& Haverkort (1994) discussed different alternatives to improve yields in this double cropping system. The authors concluded that for the spring crop improvements in fertilization rate and harvest time should be achieved, while for the autumn crop improvement in seed physiological age is needed. For Balcarce, the LINTUL-POTATO model established a potential yield of $126 \mathrm{tha}^{-1}$ for a medium-late crop cycle of 140 days while the at tainable yield and the average actual yields are 100 and $30 \mathrm{t} \mathrm{ha}^{-1}$, respectively. In this case, differences between attainable and actual yield can be attributed to differences in water and fertilizer management (Huarte, 1996) and in control of early blight ( $A$. solani) and late blight ( $P$. infestans).

These and other potential yield figures presented in Table 5 are in general agreement with the approximate estimates of van Keulen \& Stol (1995) for the region under study. A detailed and comprehensive analysis of potential and actual yields in different agro-ecological zones of the country will be the subject of a later paper.

\section{Perspectives}

Several key improvements in potato production have been achieved during the last 10 years. These include: the self-sufficiency in seed supply achieved since 1985 (Escarrá, 1989); the development of new cultivars with a short absolute dormant 
period to be grown in the early season crop including clones 87.802 .8 and 88.1000 .4 obtained by the EEOC (Zamudio, 1996); the development of cultivars for the processing industry including Frital INTA and the potential of other cultivars such as Kennebec, Ballenera MAA. Araucana INTA and Serrana INTA (Huarte, 1996); the adoption of soil conservation and weed management techniques (Lanfranconi, 1993); the production of organic seed crops in the Malargüe area (Ortego, 1996) and the increasing export market of seed and ware potatoes to MERCOSUR (Brasil, Paraguay and Uruguay) and to other countries, Germany, Bolivia, Canada (Caldiz \& Inchausti, 1996).

However, various different YLF's and YRF's, as discussed in this paper, should be considered in the future to obtain further improvements in yield and quality. The isolation of the seed areas and the exclusive use of certified seed in each of them require further controls; otherwise the achievements of the last 10 years will be lost. The use of seed with suitable physiological age according to the different planting seasons and export requirements should be considered a pre-requisite to obtain higher yield under different situations; an improved management of the new cultivars and those required by the food processing industry, such as Shepody, Russet Burbank, Ranger Russet, Atlantic, Frital INTA and Keluné INTA is needed. The development of new production areas in patagonic river valleys, like the Río Negro and Chubut, will require specific crop management, regarding improvements in soil structure, labour, wind protection, irrigation and fertilization. Increase in storage facilities for seed, ware and processing tubers are needed at country level and further identification of YLF's or YRF's and assessment of the potential yield of the crop for the different areas are also required. In this respect work is in progress to assess the possibilities of expansion and the potential crop yield in the country.

This case study of the potato production system in Argentina might be used as a model to analyze potato production in other countries, regions or continents in order to establish the actual yield of the crop, its constraints and future possibilities based on the introduction of new cultivars or different technological advances.

\section{Acknowledgements}

This work was carried out with the grant, BID 802 OC/AR PID: 665, SECyT, Agencia Nacional de Promoción Científica y Tecnológica, Argentina.

The authors wish to thank all colleagues who provided useful data for the preparation of this survey as personal communications. The valuable information provided by Ing.Agr. L. Lanfranconi (INTA Río Primero. Córdoba) regarding the situation in the province of Córdoba and his critical comments on the final version of the paper are gratefully acknowledged. Thanks are due to Mrs Laura Fernández and Mrs Fernanda Gaspari for their technical assistance in the preparation of this paper.

Disclaimer: The mentioning of the occurrence of yield reducing factors does not mean that produce (seed, ware or industry) that is sold on national or international markets carries pathogens or their survival structures. 


\section{References}

Anonymous, 1954. La papa en el sudeste de la provincia de Buenos Aires, Cámara de Productores y Acopiadores de Papa. Balcarce. Argentina, 144 pp.

Anonymous, 1989. Principales regiones productoras de papa de la República Argentina. Guipap 1989. Enfoques del Sudeste. Mar del Plata, pp. 21-32.

Anonymous, 1998. La necesidad de exportar a Brasil semilla de papa de calidad superior. Noticias CyT, Boletin de la Secretaria de Ciencia y Tecnología Año 2 (3): 6-10.

Caldiz, D.O., 1983. Seed potato production in Argentina. Proceedings 6th Symposium International Society for Tropical Root Crops. Lima, Perú, 21-26 February, 1983.

Caldiz, D.O., 1991. Influence of origin and storage system on physiological age, crop growth and tuber yield of seed potato (Solanum tuberosum L.). Indian Journal of Agricultural Research 61: 1-6.

Caldiz, D.O., 1994. Genetic Improvement and Associated Physiological Changes in the Potato. In: G.A. Slafer (Ed.), Genetic Improvement of Field Crops. Marcel Dekker, New York, pp. $361-411$.

Caldiz, D.O., 1996. Efectos del manejo del cultivo y el almacenamiento sobre la productividad de papa semilla en la Argentina. Primer Seminario de Refrescamiento del "Intermational Potato Course" para Alumnos de América Latina y el Caribe. IAC-Holanda y MINAG-Cuba. La Habana, Cuba, 19 February-1 March. 1996. 11 pp.

Caldiz, D.O. \& J. Beltrano, 1992. Physiology and improvement of potatoes (Solanum tuberosum L.). Transactions of the Malaysian Society of Plant Physiology 3: 80-83.

Caldiz, D.O.. G. Brocchi, J. Alaniz \& C. Marchan, 1996. Effects of the physiological age of seed potatoes on tuber initiation and starch and dry matter accumulation. Pesquisa Agropecuaria Brasileira 31: 853-858.

Caldiz, D.O.. O.H. Caso, G. Vater \& L.V. Fernández, 1999. The potential for production of high quality seed potatoes in Tierra del Fuego Island, Argentina. Potato Research 42:9-23.

Caldiz, D.O., F.K. Claver \& A.R. Escande. 1984. Effect of harvesting time and storage system on the quality of seed potato tubers. Turrialba $34: 287-290$.

Caldiz, D.O.. L.V. Fernández, F. Marco \& A. Clúa, 1997. Efectos de la hidrazida maleica sobre el rendimiento. contenido de materia seca y brotación en papa (Solamum tuberosum L. cv. Spunta) destinada al consumo fresco. Revista de la Facultad de Agronomía, La Plata 102: 163-173.

Caldiz, D.O. \& L.V. Fernández. 1995. Edad fisiológica de los tubérculos de papa producidos en la Argentina y sus implicancias para el cultivo posterior. I Seminario Latinoamericano da Cultura da Batata. Cámara Latinoamericana do Paraná, Curitiba, Brasil, 7-11 March 1995.

Caldiz, D.O. \& A.J. Haverkort, 1994. Alternativas para incrementar la producción de papa en el área de Villa Dolores, Córdoba. Gaceta Agronómica 14: 186-189.

Caldiz. D.O. \& M.H. Inchausti. 1996. Situación actual de la producción de papa en la Argentina. Primer Seminario de Refrescamiento del "International Potato Course" para Alumnos de América Latina y el Caribe. IAC-Holanda y MINAG-Cuba, La Habana, Cuba, 19 February-1 March, 1996, $10 \mathrm{pp}$.

Cantos de Ruiz, S., 1988. Rendimiento potencial del cultivo de papa en Balcarce. Causas que limitan la productividad real. MSc Thesis, Facultad de Ciencias Agrarias, UN Mar del Plata. Balcarce. Argentina, $60 \mathrm{pp}$.

Chiarlo, N., 1996. Legislación y evolución de la producción de papa semilla en Malargüe. Actas III Jornadas Técnicas de Papa Semilla. Papa Semilla Para Latinoamerica. Malargüe, 14-16 February, 1996, pp. 21-28.

Ediciones Aguilar, 1992. Atlas Clarín. Arte Gráfico Editorial Argentino S.A., pp. 279.

Echeverría, H.E., E.E. Suero \& F.H. Andrade, 1992. Radiación. temperatura, nutrientes y agua como determinantes de la producción del cultivo de papa. Boletín Técnico 103. EEA Balcarce, 19 pp.

Escande, A.R., D.O. Caldiz \& J.C. Rodriguez, 1986. Influencias del sistema de plantación y de la época de plantación sobre la productividad de tubérculos de papa (Solanum tuberosum L.) simiente. Turrialba 36: 237-244. 
Escande, A.R., A. Melegari, D.O. Caldiz, J.C. Rodriguez, H. Palladino \& R.H. Mirón, 1985. Influencias del sistema de almacenamiento sobre la capacidad simiente de tubérculos de papa (Solanum tuberosum L. cvs Spunta y Sierra Volcán). IDIA 440: 24-30.

Escarrá, A.M., 1989. Etapa de consolidación del abastecimiento. Hacia la exportación de semilla? Enfoques del Sudeste 51: 9-10 \& 13.

Fahem, M. \& A.J. Haverkort, 1988. Comparison of the growth of potato crops grown in autumn and spring in North Africa. Potato Research 31: 557-568.

FAO, 1990. FAOCLIM Global Weather database. Release 1990. Agrometeorology Group. Remote Sensing Centre, Research and Technology Division, FAO, Rome, Italy.

FAO, 1995. Production Yearbooks 1948-1995. FAO, Rome, Italy.

Haverkort, A.J. \& D.O. Caldiz, 1994. Aardappelproduktie in Argentinië. Aardappelwereld Magazine 48: 18-20.

Huarte, M.A., 1989. Situación actual de la producción de tubérculo-semilla de papa en la Argentina. In: O.A. Hidalgo y H. Rincón (Eds), Avances en la Producción de TubérculoSemilla de Papa en los Países del Cono Sur. CIP, Lima, Perú, pp. 15-21.

Huarte, M.A., 1994. Determinación de prioridades de investigación en papa. Simposio-Taller: Eficiencia en la producción y comercialización de papa. ASAHO e INTA, Huerta Grande, Córdoba, 26-30 September, 1994.

Huarte, M.A., 1996. Situación de la producción de papa en la Argentina (1995-96). Actas III Jornadas Técnicas de Papa Semilla. Papa Semilla Para Latinoamerica. Malargüe, 14-16 February, 1996, pp. 40-44.

Huarte, M.A. \& E. Cacace, 1998. Producción de papa para la industria. Conferencia, 4ta Agrodemostración del Sudeste, organizada por el INTA Balcarce. Unpublished.

Huarte, M.A. \& M.H. Inchausti, 1994. La producción de papa en la República Argentina y su relación con el Mercosur. Simposio de Horticultura. Montevideo, Uruguay, June 1994, 23 pp.

INTA Balcarce, 1980. Historia del cultivo de la papa en la República Argentina. Actas Segunda Reunión Nacional de Programación de Papa. Balcarce, Argentina, pp. 1-18.

Keulen, H. van \& W. Stol, 1995. Agro-ecological zonation for potato production. In: A.J. Haverkort \& D.K.L. MacKerron (Eds), Potato ecology and modelling of crops under conditions limiting growth. Kluwer Academic Press, pp. 357-372.

Kooman, P.L., 1995. Yielding ability of potato crops as influenced by temperature and daylength. $\mathrm{PhD}$ Thesis, Wageningen Agricultural University, Wageningen. The Netherlands, $155 \mathrm{pp}$.

Kooman, P.L. \& A.J. Haverkort, 1995. Modelling development and growth of the potato crop influenced by temperature and daylength: LINTUL_POTATO. In: A.J. Haverkort \& D.K.L. MacKerron (Eds), Potato ecology and modelling of crops under conditions limiting growth. Kluwer Academic Press, pp. 41-60.

Lanfranconi, L.E., 1993. Recopilación sobre el control integrado de malezas en el cultivo de papa. Un avance para su discusión. INTA, EEA Manfredi, $22 \mathrm{pp}$.

Lanfranconi, L.E., 1994. Competitividad del cultivo de la papa de la Provincia de Córdoba en el marco del MERCOSUR. INTA, Agencia Extensión Rural Río Primero, Córdoba, Argentina, $8 \mathrm{pp}$.

Mendiburu, A.O., 1986. Antecedentes de la producción de "semilla" en la Argentina. Reunión Técnica en Producción de Semilla Básica, Chacra Experimental de Miramar, Noviembre de 1986.

Mendiburu, A.O. \& O. Lucarini, 1980. Manipulaciones genéticas para la producción y el aprovechamiento de la papa. Revista de la Facultad de Agronomía, Buenos Aires 1: 129-139.

Midmore, D.J., 1990. Influence of temperature and radiation on photosynthesis, respiration and growth parameters of the potato. Potato Research 33: 293-294.

Munck, C., 1940. El cultivo de la papa en la zona sudeste de la provincia de Buenos Aires. Publicación $\mathrm{N}^{\circ} 27$ FFCC Sud y Oeste, Sección Fomento Rural, Establecimiento Gráfico Argentino, Buenos Aires, Argentina, 83 pp.

Orell, R., 1990. Papa semilla de Tafí del Valle. Actas Jornada de Actualización Técnica en Papa. AIA Balcarce - Agencia de Extensión INTA Balcarce, Balcarce, pp. 5-10. 
Ortego, J., 1996. Producción de papa semilla sin uso de biocidas en Malargüe, Mendoza. Actas III Jornadas Técnicas de Papa Semilla. Papa Semilla Para Latinoamerica. Malargüe, 14-16 February, 1996, pp. 29-33.

Penning de Vries, F.W.T. \& R. Rabbinge, 1995. Models in research and education, planning and practice. In. A.J. Haverkort \& D.K.L. MacKerron (Eds), Potato ecology and modelling of crops under conditions limiting growth. Kluwer Academic Press, pp. 1-18.

Petterssen, S., 1976. Introducción a la meteorología. Espasa-Calpe S.S., Madrid. pp. 395-412.

Rodriguez Quijano, P.A., 1989. La selección de tecnología por los agricultores. El caso de las variedades de papa en el sudeste de la provincia de Buenos Aires, Argentina. MSc Thesis, Facultad de Agronomía, UBA-INTA, Buenos Aires, Argentina, 105 pp.

Rojas, E., E.V. Viirsoo \& J. Ploper, 1975. Producción de papa semilla en Tafí del Valle. Revista Industrial y Agrícola de Tucumán 52: 61-76.

Rojas, E., E.V. Viirsoo \& N. Zamudio. 1979. Resultados obtenidos en cultivos de primicia con papa semilla multiplicada en Tafí del Valle. Revista Industrial y Agricola de Tucumán 56: 1-9.

SAGyP, 1989. Mapa de suelos de la Provincia de Buenos Aires. Secretaría de Agricultura. Ganadería y Pesca, INTA. CIRN. Instituto de Evaluación de Tierras, Buenos Aires. 525 pp.

SAGyP, 1990. Atlas de suelos de la República Argentina Tomo I y II. Secretaría de Agricultura, Ganadería y Pesca, INTA. CIRN. Buenos Aires, Argentina.

SAGyP, 1995. Estadísticas Agropecuarias y Pesqueras Año 1994. Secretaría de Agricultura. Ganadería y Pesca, SIIAP. Buenos Aires, Argentina, pp. 97-118.

SAGPyA, 1997. La Siembra y la Cosecha. El Crecimiento del Sector Agropecuario y Pesquero Argentino. Secretaría de Agricultura, Ganadería. Pesca y Alimentación. Buenos Aires, Argentina, $107 \mathrm{pp}$.

SAGPyA, 1998. Estimaciones Agrícolas. Hortalizas. Secretaría de Agricultura. Ganadería. Pesca y Alimentación. Sistema Integrado de Información Agropecuaria y Pesquera, 1998. Web page: siiap.sagyp.mecon.ar.

Saluzzo, J.A.. 1994. Comportamiento de cultivares de papa con distintio ciclo en respuesta a la fertilización nitrogenada. MSc Thesis. Facultad de Ciencias Agrarias UN Mar del Plata INTA Balcarce, Balcarce, $52 \mathrm{pp}$.

Servicio Meteorológico Nacional, 1992. Estadísticas Climáticas 1981-90. Serie B N³7, Capital Federal. Argentina.

Sívori, E.M., 1951. La degeneración de la papa. Ciencia e Investigación 8: 289-336.

Soil Survey Staff, 1992. Keys to soil taxonomy. 5th Edition. SMSS Technical Monograph $\mathrm{N}^{\circ} 19$. Blacksburg, Virginia, Pocahontas Press Inc., $556 \mathrm{pp}$.

Stol, W., G.H.J. de Koning, P.L. Kooman, A.J. Haverkort, H. Van Keulen \& F.W.T. Penning de Vries, 1991. Agro-ecological characterization for potato production. Report 155, CABODLO.P.O. Box 14.6700 AA Wageningen. The Netherlands.

Zaag, D.E. van der \& W.G. Burton. 1978. Potential yield of the potato crop and its limitations. Survey of Conference Papers 7th Triennial Conference of the EAPR. Warsaw, Poland, pp. 7-22.

Zamudio, N.. 1996. Mejoramiento de poblaciones y obtención de variedades precoces y de dormición corta en Tucumán, Argentina. Primer Seminario de Refrescamiento del "International Potato Course" para Alumnos de América Latina y el Caribe. IAC-Holanda y MINAG-Cuba, La Habana, Cuba, 19 February-1 March, 1996. 